randomly allocated to receive ligation, we controlled for factors which might have invalidated the comparison of pregnancy rates -namely, unequal duration of follow up and other differences in characteristics affecting pregnancy rates in the two groups.

Interestingly, the presence of varicoceles is itself a positive prognostic factor for fertility. Patients with varicoceles produced higher pregnancy rates than those without whether or not testicular vein ligation had been performed and despite the lower sperm concentrations. Why varicoceles should be associated with better fertility in the subfertile population is uncertain. Details of this and other prognostic factors will be reported elsewhere.

Apart from an increase in sperm motility, there was no significant change in the results of semen analysis after testicular vein ligation. The increase in sperm motility was probably not due to treatment of the varicocele as it was matched by a similar increase in men with varicoceles who had not received ligation. We have also noted that sperm motility increases with time in other groups of infertile men and during the placebo phase of a controlled trial of treatment with erythromycin for low sperm motility. These spontaneous improvements may be attributed to selection bias and regression towards the mean. ${ }^{116}$

Our results strongly suggest that testicular vein ligation is not effective in increasing fertility and confirms other reports that doubt the value of treatment of varicoceles in infertile men. ${ }^{568}$ Onus is now on proponents of the treatment of varicoceles in infertile men by operation or other techniques to prove their case.

This work was supported by the National Health and Medical Research Council of Australia. We thank Ms Nola Balas, Mrs Ann Stewart, and Mrs
Elsa Newman, for help with data coding and computing, and Diane Hollingsworth, for typing.

\section{References}

1 Verstoppen GR, Steeno OP. Varicocele and the pathogenesis of the associated subfertility. A review of the various theories II: results of surgery. Andrologia 1977;9:293-305. review of the various theories II: results of surgery.
Saypol DL. Varicocele. Int $\mathcal{I}$ Androl 1981;2:61-71.

2 Saypol DL. Varicocele. Int $\mathcal{I}$ Androl 1981;2:61-71.

3 Cockett ATK, Takihara H, Cosentino JM. The varicocele. Fertil Steril 1984;41:5-11.

4 Uehling DT. Fertility in men with varicocele. Int $f$ Fertil 1968;13:58-60.

Rodriguez-Rigau LJ, Smith KD, Steinberger E. Relationship of varicocele to sperm output and fertility of male partners in infertile couples. $\mathcal{F}$ Urol 1978;120:691-4.

6 Nilsson S, Edvinsson A, Nilsson B. Improvement in semen and pregnancy rate after ligation and division of the internal spermatic vein: fact or fiction. $B r$ J Urol 1979;51:591-6.

7 De Castro MPP, Mastrorocco DAM. Reproductive history and semen analysis in prevasectomy fertile men with and without varicocele. F Androl 1984;5:17-20.

8 Vermeulen A, Vandeweghe $\mathrm{M}$. Improved fertility after varicocele correction: fact or fiction? Fertil Steril 1984:42:249-56.

9 Palomo A. Radical cure of varicocele by a new technique: preliminary report. $\mathcal{J}$ Urol 1949;61:604

10 Belsey MA, Eliasson R, Gallegos AJ, Moghissi KS, Paulsen CA, Prasad MRN. Laboratory manual for the examination of human semen and semen-cervical mucus interaction. Singapore: Press

11 Baker HWG, Burger HG, de Kretser DM, Lording DW, McGowan MP, Rennie GC. Factors affecting the variability of semen analysis results in infertile men. Int $f$ Androl 1981;4:609-22.

affecting the variability of semen analysis results in infertile men. Int $\mathcal{A}$ Androl 1981;4:609-22.
Baker HW'G, Burger HG, de Kretser DM, Hudson B. Relative incidence of etiologic disorders in male infertility. In: Santin RJ, Swerdloff RS, eds. Male sexual disfunction: diagnosis and male infertility. In: Santin RJ, Swerdloff RS, eds. Male sexual disfunction: diagnosis and management of hypogonadism, infertility and impotence. New York: Marcel Dekker (in press).

13 Peto R, Pike MC, Armitage P, et al. Design and analysis of randomized clinical trials requiring prolonged observation of each patient. II analysis and examples. Br f Cancer 1977;35:1-39.

14 Cox DR. Regression models and life tables. $\mathcal{F} R$ Stat $S_{o c}$, Series $B$ 1972;34:187-220.

15 Hopkins A. Survival analysis with covariates-Cox models. In: Dixon WJ, ed. BMDP statistical software. Berkeley: University of California Press, 1983:576-94

16 Baker HWG, Straffon WGE, McGowan MP, Burger HG, de Kretser DM, Hudson B. A controlled trial of the use of erythromycin for men with asthenospermia. Int $\mathcal{f}$ Androl 1984;7:383-388.

Accepted 8 October 1985

\title{
Electrolyte disturbances and cardiac failure with hypomagnesaemia in anorexia nervosa
}

\author{
V FONSECA, C W H HAVARD
}

\begin{abstract}
A 32 year old woman with anorexia nervosa was admitted to hospital with severe hypocalcaemia and hypokalaemia that was refractory to replacement treatment but that responded immediately to an infusion of magnesium. She also had congestive cardiac failure that responded to magnesium replacement. The mild hypomagnesaemia found in this patient was responsible for the refractory hypocalcaemia.

Minor deficiencies of magnesium may cause severe hypocalcaemia and hypokalaemia that are refractory to replacement treatment. Prompt replacement of magnesium may prevent prolonged tetany, cardiac arrhythmias, and heart failure.
\end{abstract}

\section{Introduction}

Hypomagnesaemia is associated with hypocalcaemia and hypokalaemia,' but the importance of magnesium deficiency in the aetiology of these electrolyte disturbances is not always appreciated. We report a patient with anorexia nervosa who presented with

Royal Free Hospital, London NW3

V FONSECA, MD, MRCP, senior registrar

C W H HAVARD, MD, FRCP, consultant physician and endocrinologist

Correspondence to: Dr Havard. severe hypocalcaemia and hypokalaemia that was refractory to replacement treatment but that responded immediately to an infusion of magnesium. In addition, she developed congestive cardiac failure that responded to magnesium replacement.

\section{Case report}

A 32 year old woman was admitted to hospital with weakness, paraesthesiae, and tetany. She had a long history of anorexia nervosa with chronic laxative and diuretic abuse. She had been admitted several times previously and on one occasion, a year before this latest admission, suffered a cardiorespiratory arrest, from which she was resuscitated. Apart from multivitamins, she denied taking any treatment. On examination she weighed $27 \mathrm{~kg}$. She was pale and cachectic but did not have rardiac failure. There was noticeable proximal muscle weakness as she could not raise her legs off the bed. Reflexes, however, were all present and equal, and there were no objective sensory changes. Systemic examination showed no other abnormality.

Her packed cell volume was $0 \cdot 19$; haemoglobin concentration $62 \mathrm{~g} / \mathrm{l}$; leucocyte count $12.5 \times 10^{9} / 1$; and concentrations of plasma urea $13.7 \mathrm{mmol} / \mathrm{l}$ $(82.5 \mathrm{mg} / 100 \mathrm{ml})$, plasma potassium $1.4 \mathrm{mmol}(\mathrm{mEq}) / \mathrm{l}$, plasma sodium 138 $\mathrm{mmol}(\mathrm{mEq}) / 1$, plasma bicarbonate $18 \mathrm{mmol}(\mathrm{mEq}) / 1$, plasma calcium $1 \cdot 71$ $\mathrm{mmol} / 1(6.84 \mathrm{mg} / 100 \mathrm{ml})$, plasma phosphate $0.56 \mathrm{mmol} / 1(1.7 \mathrm{mg} / 100 \mathrm{ml})$, plasma creatinine $140 \mu \mathrm{mol} / \mathrm{l}(1.6 \mathrm{mg} / 100 \mathrm{ml})$, and plasma albumin $26 \mathrm{~g} / \mathrm{l}$. Radiographs of her chest showed clear lung fields.

The patient was given a blood transfusion (four units of packed cells) and, in addition, an intravenous infusion of potassium chloride $(20 \mathrm{mmol}$ in $5 \%$ dextrose) with $1 \mathrm{~g}$ of added calcium gluconate every six hours for the next 10 days. She received 21 of fluid intravenously daily. Her haemoglobin concentration rose to $114 \mathrm{~g} / \mathrm{l}$, plasma albumin rose to $30 \mathrm{~g} / \mathrm{l}$, and blood urea fell to $5.8 \mathrm{mmol} / 1(35 \mathrm{mg} / 100 \mathrm{ml})$, but plasma calcium and potassium concentrations remained low at $1.95 \mathrm{mmol} / 1(7.8 \mathrm{mg} / 100 \mathrm{ml})$ and $3.5 \mathrm{mmol} / \mathrm{l}$, 
respectively. The patient still had paraesthesiae and proximal muscle weakness with regular episodes of tetany. A week after admission she developed dyspnoea and peripheral oedema with a raised jugular venous pressure and pleural effusion. Chest radiographs showed pulmonary oedema and cardiac dilatation as well as a pleural effusion (figure). Her electrocardiogram was normal. She was treated with frusemide $80 \mathrm{mg}$ daily and amiloride $10 \mathrm{mg}$ daily for five days with poor response. Unfortunately, it was not possible to measure accurately the intake and output of fluid as the patient would not comply.

Further investigations showed concentrations of plasma magnesium 0.56 $\mathrm{mmol} / \mathrm{l}(1.4 \mathrm{mg} / 100 \mathrm{ml}$ ) (normal range $0.70-1.0 \mathrm{mmol} / 1 ; 1 \cdot 7-2.4 \mathrm{mg} / 100$ $\mathrm{ml}$ ), serum parathyroid hormone $56 \mathrm{pmol} / \mathrm{l}(29-85 \mathrm{pmol} / \mathrm{l})$, serum 25hydroxyvitamin $\mathrm{D}_{3} 51 \mathrm{nmol} / \mathrm{l}(2 \cdot 1 \mu \mathrm{g} / 100 \mathrm{ml})(15-54 \mathrm{nmol} / \mathrm{l} ; 0 \cdot 6-2 \cdot 3 \mu \mathrm{g} / 100$ $\mathrm{ml})$; erythrocyte transketolase activity $74 \mathrm{IU} / \mathrm{l}$ (34-90 IU/1); and thiamine pyrophosphate effect $7 \%(3 \cdot 5-40 \%)$.

The patient was given an infusion of magnesium sulphate $48 \mathrm{mmol}$ over 24 hours. The next day her plasma calcium concentration had risen to $2 \cdot 1$ $\mathrm{mmol} / \mathrm{l}(8.4 \mathrm{mg} / 100 \mathrm{ml})$, plasma potassium to $5.4 \mathrm{mmol} / \mathrm{l}$, and plasma magnesium to $0.75 \mathrm{mmol} / 1(1.8 \mathrm{mg} / 100 \mathrm{ml})$. Replacement of calcium and potassium was stopped. Plasma calcium concentration rose further over the next two days to $2 \cdot 3 \mathrm{mmol} / 1(9.2 \mathrm{mg} / 100 \mathrm{ml})$, and plasma potassium concentration stabilised at $4.4 \mathrm{mmol} / \mathrm{l}$. Serum parathyroid hormone activity rose to $123 \mathrm{pmol} / \mathrm{l}$ after the magnesium infusion. The congestive cardiac failure rapidly resolved over the new few days, and the patient became asymptomatic. Over the next six months her plasma magnesium concentration remained within the normal range and the size and functioning of her heart remained normal.

\section{Discussion}

The mild degree of hypomagnesaemia in this patient was clearly responsible for the refractory hypocalcaemia. The rise in plasma calcium concentration, which had been resistant to replacement treatment, and the rise in serum parathyroid hormone activity were immediate after magnesium replacement. Impaired secretion of parathyroid hormone in response to hypocalcaemia occurs in the presence of hypomagnesaemia, ${ }^{23}$ though it is not widely appreciated that the inhibition of secretion may occur with minor deficiencies of magnesium. Furthermore, hypomagnesaemia is less likely to be suspected in a patient with a nutritional disorder who would initially be considered to have vitamin $\mathrm{D}$ deficiency as a cause for hypocalcaemia. ${ }^{4} \mathrm{~A}$ small amount of magnesium given intravenously restored the plasma magnesium concentration to normal. This is probably because magnesium, like potassium and calcium, is essentially an intracellular ion. It has been established that hypomagnesaemia and the related hypocalcaemia can be corrected by surprisingly small amounts of intravenous magnesium. ${ }^{12}$

We have reviewed 15 patients admitted to this hospital with anorexia nervosa and have not observed hypomagnesaemia, though some of them had vitamin D deficiency. ${ }^{4}$ In a recent review of the medical complications of bulimia Jacobs and Schneider claimed that the marginal decrease in the serum magnesium concentration did not warrant its routine determination. ${ }^{5}$ Hypokalaemia also occurs as a consequence of hypomagnesaemia. ${ }^{1}$ Furthermore, intracellular potassium concentration is reduced in the cardiac muscle of hypomagnesaemic animals, ${ }^{1}$ and hypokalaemia causes morphological changes in the myocardium in rats. ${ }^{6}$ These abnormalities may have contributed to the unexplained cardiac failure during this admission of our patient and perhaps to the cardiac arrhythmias and cardiac arrest in the past. Cardiomyopathy may be associated with hypokalaemia. ${ }^{7}$ Although the aetiological role of hypomagnesaemia in inducing cardiac arrhythmia remains controversial, modest hypomagnesaemia has been reported to cause cardiac arrhythmias. Powers described three patients who developed heart failure during treatment of anorexia nervosa. ${ }^{8}$ Plasma magnesium concentrations were not measured in any of these patients, though one had had a low plasma calcium concentration that had returned to normal by the time the heart failure had resolved.

It is difficult to implicate hypomagnesaemia as the cause of proximal myopathy in our patient as this may have resulted from associated hypocalcaemia. Several other neurological and psychiatric features have been described in the presence of hypo-
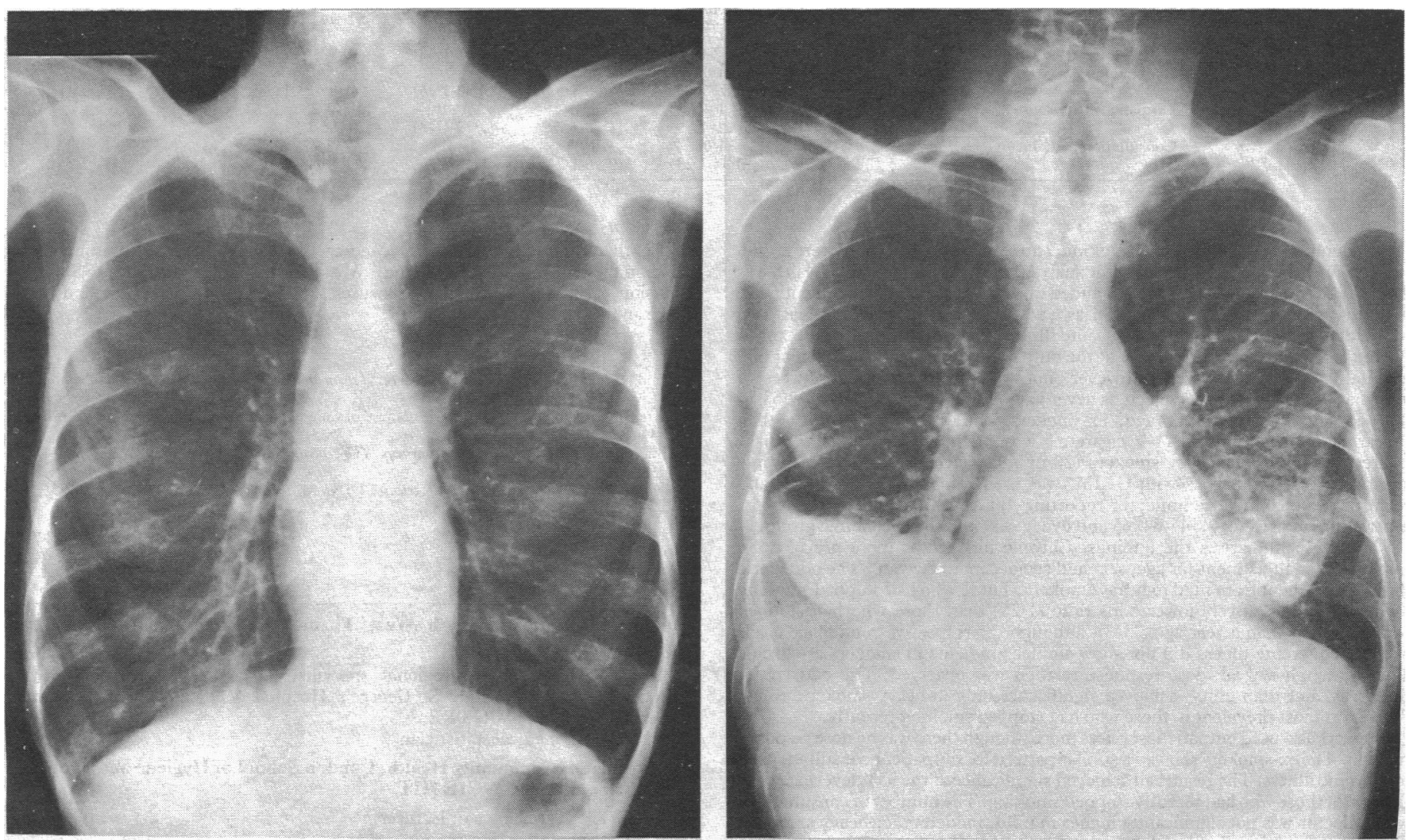

Chest radiograph. Left: on admission to hospital; right: after development of cardiac failure. 
magnesaemia and hypocalcaemia,' and it is impossible to assess the true contribution to symptoms of either magnesium or calcium.

Minor deficiencies of magnesium may cause severe hypocalcaemia and hypokalaemia that are refractory to replacement treatment. Prompt replacement of magnesium may prevent prolonged tetany, cardiac arrhythmias, and heart failure.

\section{References}

I Brenton DP, Gordon TE. Fluid and electrolyte disorders: magnesium. Br $\mathcal{f}$ Hosp Med 1984;32 $60-9$
2 Anast CS, Winnacker JL, Forte LR, Burns TW. Impaired release of parathyroid hormone in magnesium deficiency. $\mathcal{F}$ Clin Endocrinol Metab 1976;42:707-17

3 Freedman DB, Shannon M, Dandona P, Prentice HG, Hoffbrand AV. Hypoparathyroidism and hypocalcaemia during treatment for acute leukaemia. BrMed f 1982;284:700-2.

4 Fonseca V, Houlder S, Thomas M, DeSouza V, Wakeling A, Dandona P. Osteopenia in wome with anorexia nervosa. $N$ Engl f Med 1985;313:326.

5 Jacobs MB, Schneider JA. Medical complications of bulimia. A prospective evaluation. Quart $\mathcal{f}$ Med 1985;54:177-82.

Molnar Z, Larsen K, Spargo B. Cardiac changes in the potassium depleted rat. Arch Pathol 1962;74:339-47.

7 Potts JL, Dalakos TG, Streeten DH, Jones D. Cardiomyopathy in an adult with Bartter's syndrome and hypokalaemia. Am $\mathcal{J}$ Cardiol 1977;40:995-9.

8 Powers PS. Heart failure during treatment of anorexia nervosa. Am f Psychiatry 1982;139:1167-70.

(Accepted l October 1985)

\section{SHORT REPORTS}

\section{Smoking and state of health}

Cigarette smoking is the largest single external factor contributing to mortality in the British Isles. The number of deaths attributed to smoking is about 100000 a year. ' The cost to the National Health Service of diseases to which smoking is a major contributory factor is estimated to be $\$ 170 \mathrm{~m}$ year. ${ }^{2}$ Little research has been published on morbidity in general or the use of services by smokers and non-smokers. We explored these aspects using the General Household Survey for 1980

\section{Methods and results}

The General Household Survey, based on a sample of the population resident in private households in Great Britain, included information on age, sex,

\section{Comment}

In our study smokers suffered from chronic and acute illness more than non-smokers, and this increased with the number of cigarettes smoked. They also visited outpatient clinics significantly more than non-smokers, though this was not reflected in their consultations with a doctor.

Ex-smokers also showed greater risks for all variables, irrespective of how long ago they had stopped smoking. Subjects who had stopped smoking most recently consulted doctors most and also suffered most from acute illness, suggesting that they might have stopped smoking because of ill health. The higher ratios for consultations with a doctor might also be related to counselling associated with preventive strategies.

Our findings show that ill health is more prevalent in smokers and ex smokers than in non-smokers. These findings emphasise the need to concentrate on primary prevention of ill health to reduce the load on the health services from use of tobacco.

Odds ratios for variables of state of health in non-smokers, smokers, and ex-smokers. Values in brackets are $95 \%$ confidence limits

\begin{tabular}{|c|c|c|c|c|c|c|}
\hline \multirow[b]{2}{*}{ Variables } & \multirow[b]{2}{*}{$\begin{array}{l}\text { Non- } \\
\text { smokers }\end{array}$} & \multicolumn{3}{|c|}{ Smokers } & \multicolumn{2}{|c|}{ Ex-smokers } \\
\hline & & $\begin{array}{l}1-9 \text { cigarettes } \\
\text { a day }\end{array}$ & $\begin{array}{c}\text { 10-19 cigarettes } \\
\text { a day }\end{array}$ & $\begin{array}{l}\geqslant 20 \text { cigarettes } \\
\text { a day }\end{array}$ & $\begin{array}{l}\text { Stopped smoking } \\
\geqslant 1 \text { yr ago }\end{array}$ & $\begin{array}{c}\text { Stopped smoking } \\
<1 \text { yr ago }\end{array}$ \\
\hline Chronic illness & 1 & $\begin{array}{c}1 \cdot 07 \\
(0 \cdot 87-1 \cdot 31)\end{array}$ & $\begin{array}{c}1 \cdot 31 \\
(1 \cdot 12-1 \cdot 53)\end{array}$ & $\begin{array}{c}1.76 \\
(1.54-2.02)\end{array}$ & $\begin{array}{c}1 \cdot 43 \\
(1 \cdot 21-1 \cdot 68)\end{array}$ & $\begin{array}{c}1 \cdot 26 \\
(0.95-1 \cdot 67)\end{array}$ \\
\hline Acute illness & 1 & $\begin{array}{c}1.03 \\
(0 \cdot 79-1 \cdot 33)\end{array}$ & $\begin{array}{c}1.09 \\
(0.89-1 \cdot 33)\end{array}$ & $\begin{array}{c}1 \cdot 29 \\
(1 \cdot 08-1 \cdot 52)\end{array}$ & $\begin{array}{c}1 \cdot 11 \\
(0 \cdot 90-1 \cdot 38)\end{array}$ & $\begin{array}{c}1.48 \\
(1.05-2 \cdot 07)\end{array}$ \\
\hline Outpatient attendances & 1 & $\begin{array}{c}1 \cdot 46 \\
(1 \cdot 14-1 \cdot 87)\end{array}$ & $\begin{array}{c}1 \cdot 46 \\
(1 \cdot 20-1 \cdot 79)\end{array}$ & $\begin{array}{c}1 \cdot 43 \\
(1 \cdot 20-1 \cdot 72)\end{array}$ & $\begin{array}{c}1 \cdot 40 \\
(1 \cdot 29-1 \cdot 72)\end{array}$ & $\begin{array}{c}1 \cdot 25 \\
(0 \cdot 86-1 \cdot 81)\end{array}$ \\
\hline Consultation with doctor & 1 & $\begin{array}{c}1 \cdot 12 \\
(0 \cdot 96-1 \cdot 32)\end{array}$ & $\begin{array}{c}1.08 \\
(0.94-1 \cdot 23)\end{array}$ & $\begin{array}{c}1.09 \\
(0.96-1 \cdot 24)\end{array}$ & $\begin{array}{c}1.19 \\
(1.05-1 \cdot 35)\end{array}$ & $\begin{array}{c}1 \cdot 47 \\
(1 \cdot 16-1 \cdot 87)\end{array}$ \\
\hline
\end{tabular}

socioeconomic groups, history of smoking, and state of health. There were 23956 subjects over the age of 16 available for analysis. The subjects' state of health was determined in an interview, which included questions about longstanding illness, disability, or infirmity- "chronic illness"; restriction of activity in the last two weeks due to illness or disability- "acute illness"; consultation with a doctor in the last two weeks; and attendance at the outpatient or casualty department of a hospital ${ }^{3}$ These events were, however, not validated with other sources of information. We classified subjects as never having smoked, ex-smokers who had stopped less than one year ago, ex-smokers who had stopped more than a year ago, mild smokers (1-9 cigarettes a day), moderate smokers (10-19 cigarettes a day), and heavy smokers ( 20 or more cigarettes a day). Multiple logistic regression analysis with $\mathrm{GLIM}^{4}$ was used to estimate odds ratios and corresponding confidence limits for reporting "ill health" among these groups, controlling for age (16-44, 45-64, 65 and over), sex, and socioeconomic group.

The table summarises the findings. Chronic illness was more prevalent in smokers after adjustment for age, sex, and socioeconomic group. The odds ratio showed a gradient from mild to heavy smokers. Those who had stopped smoking recently had a relatively lower odds ratio $(1 \cdot 26)$ than those who had stopped smoking more than a year ago $(1 \cdot 43)$, although the respective confidence level overlapped. Acute illness did not show similar gradients in smokers as chronic illness, though a weak dose response relation was observed. The odds ratio though greater than unity, achieved significance only in heavy smokers. Acute illness was most prevalent in those who had stopped smoking recently.

Smokers also used outpatient services more, though there was no dose response relation. The ex-smokers showed a similar pattern for outpatient consultations as for chronic illness. The results all achieved significance at the $95 \%$ level except in the case of those who had recently stopped smoking. The number of consultations with a doctor was not significantly higher in mild, moderate, or heavy smokers. Ex-smokers, on the other hand, had significant odds ratios, the highest being for those who had stopped smoking recently.
We thank Dr Clive Osmond, Medical Research Council Environmental Epidemiology Unit, Southampton; Miss Amanda White, Social Surveys Division, Office of Population Censuses and Surveys, for advice; and Ann Aykiran for secretarial support.

1 Wald N. In: Bennett E, ed. Recent advances in communiv medicine-number 1. London: Churchill

Livingstone, 1978. 4;80:col 110. (No 110.)

3 Office of Population Censuses and Surveys. The general household survey 1980. London: HMSO, 1982.

4 Baker RJ, Nelder JA. GLIM system (Release 3). Oxford: Numerical Algorithm Group, 1981

Accepled 4 September 1985)

Medical Department, South West Thames Regional Health Authority, London W2 3QR

R BALARAJAN, MFCM, regional specialist in community medicine and honorary senior lecturer, St George's Hospital Medical School, Cranmer Terrace, London SW17 0RE

P YUEN, MSC, medical statistician

Department of Community Health, London School of Hygiene and Tropical Medicine, London WCIE 7HT

B R BEWLEY, FFCM, senior lecturer

Correspondence to: Dr Balarajan. 